
WELL BEING THROUGH WORK ENGAGEMENT AND CAREER SATISFACTION AS MEDIATORS

\title{
THE EFFECTS OF PSYCHOLOGICAL CAPITAL AND PERCEIVED ORGANIZATIONAL SUPPORT ON SUBJECTIVE WELL BEING THROUGH WORK ENGAGEMENT AND CAREER SATISFACTION AS MEDIATORS
}

\author{
Siti Munfaqiroh \\ STIE Malangkucecwara Indonesia \\ riroh@stie-mce.ac.id \\ Hanif Mauludin \\ STIE Malangkucecwara Indonesia \\ hanif@stie-mce.ac.id \\ Antonius Prima Nugraha \\ STIE Malangkucecwara Indonesia \\ anton.tjoek@gmail.com
}

\begin{abstract}
This study examines the relationship between Organizational Support Perceived and Psychological Capital on Subjective Welfare from employees of government organizations in Indonesia. 118 staff of the Directorate General of Taxes who participated in filling out the questionnaire. Data were analyzed using the Partial Least Square technique. The results showed that organizational support and work involvement were not proven to mediate the effect of organizational support on subjective well-being. Work engagement and career satisfaction are proven to mediate the influence of psychological capital. The practical implication proposed is the development of organizational capacity through psychological capital as the most dominant variable.

Keywords: Psychological Capital, Perceived Organizational Support, Subjective Well Being, Work Engagement, Career Satisfaction
\end{abstract}

\section{INTRODUCTION}

Job satisfaction is a feeling and a happy attitude shown by employees where there is a match between expectations and results received. Although there is an inconclusive relationship between happiness and worker productivity in the work environment, it seems to be a general agreement that if the worker is happy, he will be more productive (Diener and Biswas, 2008; Cropanzano and Wright, 2004; Zelenski et 
al, 2008). Erdogan et al. (2012) suggest that a view of happiness in the workplace depends on satisfaction with the environment, leadership influence, career development, job characteristics, and compatibility between workers and the environment. This matter used as a factor that can contribute to being able to understand happiness or well-being at work. In this study, we examine individual happiness at work, career, and the potential impact of happiness in the workplace. Although in theory work involvement, career satisfaction, and subjective well-being of individuals show the relationship between one another but empirically raises the research gap. First, the involvement of workers is a significant concern by practitioners because the involvement of workers is more motivating, more influential in their work and organization, more productive and more willing to go forward and exceed more than expected to help the organization survive and develop (Bakker and Demerouti, 2008; Gebauer and Lowman, 2008). Workers who are very involved in their work and satisfied with their careers are overall happy in their lives. Then, career satisfaction, a proxy for the perceived quality of one's work, has become an essential criterion for evaluating the career of the individual as a whole (Judge et al., 1999; Gattiker and Larwood, 1988). Career satisfaction is a reflection of individual values and a reference to compensation, challenges, or security that may have an impact on an individual's assessment of career achievements. Finally, about Subjective Well Being (SWB), researchers (e.g., Cropanzano and Wright, 1999; Lyubomirski, 2001) call the term SWB happiness. Being happy refers to what has achieved at the highest level that has reached the point of satisfaction. Happiness individually is to be more instrumental, to be oriented to the approach, to be more energetic, to be interested in his work, to sympathize with his co-workers, and to endure hardships compared to unhappy employees.

This research focuses on Perceived Organizational Support (POS) and psychological capital (PsyCap) as antecedents of well-being. According to organizational support theory (Eisenberger et al., 1986), workers form a general opinion on how far organizations value their contributions and care about their well-being. Based on the norms of reciprocity, Perceived Organizational Support (POS) will raise workers' awareness to care about the sustainability of the organization and help the organization achieve its goals. PsyCap is an individual's positive psychology for developing. PsyCap is a typical example of positive organizational behaviour, open to growth and relevant to performance (Luthans et al., 2007).

Based on these explanations, researchers are interested in studying more deeply how the influence of psychological capital and perceived organizational support on subjective well. Furthermore, this research also examines the role of work engagement and career satisfaction as mediating variables. 


\section{LITERATURE REVIEW}

In a review of the literature on life satisfaction and subjective well-being of individuals, Erdogan et al. (2012) suggest an approach for life satisfaction or happiness with two approaches. A first approach is a top-down approach (i.e., trait view: stable nature determines happiness), and second is bottom-up (i.e., social outlook: happiness depends on satisfaction with the environment). According to organizational support theory, workers will perform positively as long as the organization appreciates their contribution and concern for their well-being (Eisenberger et al., 1986; Rhoades and Eisenberger, 2002). Based on this norm of reciprocity, POS refers to the obligation borne by employees to help achieve organizational goals. A positive relationship found between POS and affective commitment (Panaccio and Vandenberghe, 2010).

PsyCap is an individual's psychological condition to develop in a positive direction (Luthans et al., 2007). Luthans et al. (2007) propose that PsyCap offers a more comprehensive and higher framework in the conceptual framework for understanding and utilizing human resource assets in organizations (Avolio and Luthans, 2006). PsyCap consists of four dimensions: self-efficacy, hope, resiliency, and optimism (Luthans et al., 2007). Self-efficacy refers to beliefs about one's ability to use cognitive resources, motivation, and a series of actions to complete various tasks in a work context. Hope refers to a state of positive motivation based on a sense of energy directed at the goal and planning to achieve the goal. Resiliency refers to the ability to overcome difficult situations and failures. Optimism is considered a characteristic of the attitude of perceiving positive things as permanent beliefs while expecting negative things to be avoided. There are several numbers of contextual factors that can affect the level of success, hope, resilience, and optimism. Luthans et al. (2007) claim that workers with high PsyCap levels are more motivated and proactive in the workplace.

Involvement is a multidimensional construct (Law et al., 1998; Rich et al., 2010). Kahn (1990) employee involvement defines as the work and expression of one's entire self (physical, cognitive, and emotional) in their work roles. We use the notion of work engagement, which defined as a positive, satisfying, thoughtrelated condition of work characterized by three dimensions: dedication, absorption, and strength (Schaufeli and Bakker, 2004). Namely, work involvement considered as deliberate and wise pursuit of work (i.e., dedication or cognitive involvement); as absorbing and attractive (i.e., emotional absorption or involvement); customer satisfaction, higher productivity and acceptance, lower turnover intentions (Harter et al., 2002), more extra-role roles and behaviours, higher organizational commitment and work-family satisfaction (Schaufeli and Bakker, 2004).

Career satisfaction is a subjective measure of career success, which refers to the positive relationship and psychological results achieved by a person as a result of work experience. Career success divided into 
two types: objective (for example, the number of promotions and salary increases) and subjective (for example, job satisfaction or career satisfaction). In their meta-analysis, Irwin.et al. (2005) said that career success can be determined by organizational sponsors such as supervisor support, career sponsors, training opportunities and skills development and organizational size. Human capital, stable individual differences, and socio-demographic status can also be factors in career success. Concerning to career satisfaction, researchers have studied individual personality, race, and organizational support for career development. Lounsbury et al. (2003) found that assertiveness, rigor, emotional resilience, and extraversion related to career satisfaction. Finally, organizational support, such as mentoring relationships, leads to higher career development perceptions.

Happiness is a welfare-oriented evaluation that requires positive excess to influence more than negative influence (Diener and Biswas, 2008). From this perspective, one's happiness can be determined by good emotional intelligence, wealth, health, stable work and quality of life in the family (Christopher, 1999; Carmeli et al., 2009). Individual Subjective Well-being consists of two general components: (a) the balance of feelings/emotions (comparison between the levels of positive and negative influences in life) and (b) an assessment of life satisfaction (Diener and Biswas, 2008; Erdogan et al. 2012). Previous researchers believe that the level of well-being is not fixed and influenced by individual impetus factors.

One significant predictor of career satisfaction is organizational support that provides career opportunities for the personal goals of its workers. (e.g., superiors' support, career sponsorships, education and training, organizational opportunities and size) (Irwin et al. 2005). When workers are satisfied with their career development programs, these workers will tend to believe that their work in the organization will increase their competence and competitiveness. Armstrong-Stassen and Ursel (2009) found that career satisfaction mediates the relationship between organizational support, job content, and job retention. So the hypothesis in this study is as follows: H1. Perceived Organizational Support positively influences career satisfaction.

Kahn (1990) conceptually states that workers perceiving the work environment can create conditions in which workers can be personally involved. In this case, each individual will be different in perception and willing to express themselves in their work. A worker who has supportive perceptions tend to be more caring, so they consciously perform more in their jobs. Saks (2006) reports that Perceived Organizational Support predicts a relationship between work engagement and organization. Positive results on the relationship between Perceived Organizational Support and affective commitment (Panaccio and Vandenberghe, 2010), in performance appraisal (Eisenberger et al., 1990), have examined the direct relationship between career involvement and satisfaction. So the hypothesis in this study is as follows: H2. Perceived Organizational Support will positively influence work engagement. 

WELL BEING THROUGH WORK ENGAGEMENT AND CAREER SATISFACTION AS MEDIATORS

According to Irwin et al. (2005) objective and subjective criteria of career success including human resources (such as the number of hours worked, work involvement, years of work, work tenure, work experience, willingness to share, level of education, career planning, political knowledge and expertise, and social capital) and permanent individual differences (such as Big Five personal, proactive, control over locus and cognitive abilities) factors. Several studies report a positive relationship between Psychological Capital and well-being. Avery et al. (2010) suggest that Psychological Capital and employee welfare positively related at all times. So the hypothesis in this study is as follows: H3. Psychological Capital will positively influence career satisfaction.

According to Avery et al. (2011), a meta-analysis of Psychological Capital, although previous studies have examined the impact of Psychological Capital on employee behaviour and attitudes such as job satisfaction, organizational commitment, organizational reach, performance and attitudes, and undesirable behaviours. Previous research only found one study (Avery et al. 2008) that empirically explained the direct relationship between Psychological Capital and job satisfaction. So the hypothesis in this study is as follows: H4. Psychological Capital will positively influence work engagement.

Work engagement is the perception of workers at work that is meaningful, physical, emotional and psychologically safe (Rich et al., 2010) Traditional job satisfaction studies have shown that work and life satisfaction are strictly related to each other (Judge and Kameyer-Mueller, 2011). Research has shown that the workers involved are energetic and highly capable individuals who believe that what they do will affect their lives (Schaufeli and Bakker, 2004). H5. Job involvement will positively influence career satisfaction.

While several studies have examined the relationship between job satisfaction and subjective well-being, only a few studies have examined the relationship between career satisfaction and Individual Subjective Welfare (Erdogan et al., 2012). Previous research believes that when workers feel very involved with their work, they will be more satisfied with the achievement of their careers, and thus, one level of happiness will also be higher. H6. Career satisfaction will positively affect individual subjective well-being.

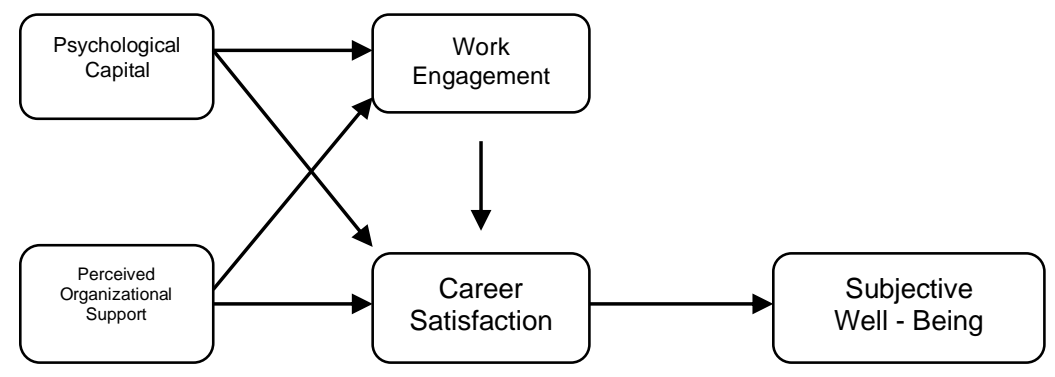

FIGURE 1. RESEARCH MODEL

Source: Created by authors, based on literature review 


\section{RESEARCH METHODS}

The study design uses explanatory research, which is to explain the causal relationship between research variables and test hypotheses. The research sample was taken by purposive sampling by considering work period and seniority, experience in leading a division and having received an award. Data collection was made by using a questionnaire both online and physically. The number of respondents who participated in filling out the questionnaire was 118 employees of the tax directorate in Indonesia.

\subsection{Variables and measurement}

Perceived Organizational Support (POS) is measured by 8 indicators adapted from Rhoades et al. (2001. Psychological Capital (PsyCap is measured by 12 PsyCap Questionnaire (PCQ) indicators taken from Luthans et al. (2016). Work engagement using an engagement measurement tool called the Utrecht Work Engagement Scale (UWES) was developed to determine the level of engagement (Schaufeli \& Bakker, 2004). UWES consists of 9 indicators. To measure career success subjectively, we use a 5 item career satisfaction scale developed by Greenhaus et al. (1990) to assess the level of satisfaction with various dimensions of employee careers. Individual Subjective Welfare (SWB) in measuring SWB, we adopted 3 items Subjective Happiness Scale (SHS) developed by Lyubomirsky and Lepper's (1999).

\subsection{Data analysis}

Data analysis was made by using Partial Least Square (PLS) with SmartPLS software. PLS is a variance-based structural equation analysis (SEM) to test the validity and reliability and test this research model.

\section{RESULTS AND DISCUSSION}

\subsection{Validity and Reliability test}

Based on Figure 2, the value of outer loadings for each variable that includes Psycological Capital (PsyCap), Perceived Organizational Support (POS), Work Involvement (WO), Career Satisfaction (CS) and Individual Subjective Welfare (SWB) has values above 0.6. It means all indicators used to measure variables are valid. 
THE EFFECTS OF PSYCHOLOGICAL CAPITAL AND PERCEIVED ORGANIZATIONAL SUPPORT ON SUBJECTIVE WELL BEING THROUGH WORK ENGAGEMENT AND CAREER SATISFACTION AS MEDIATORS

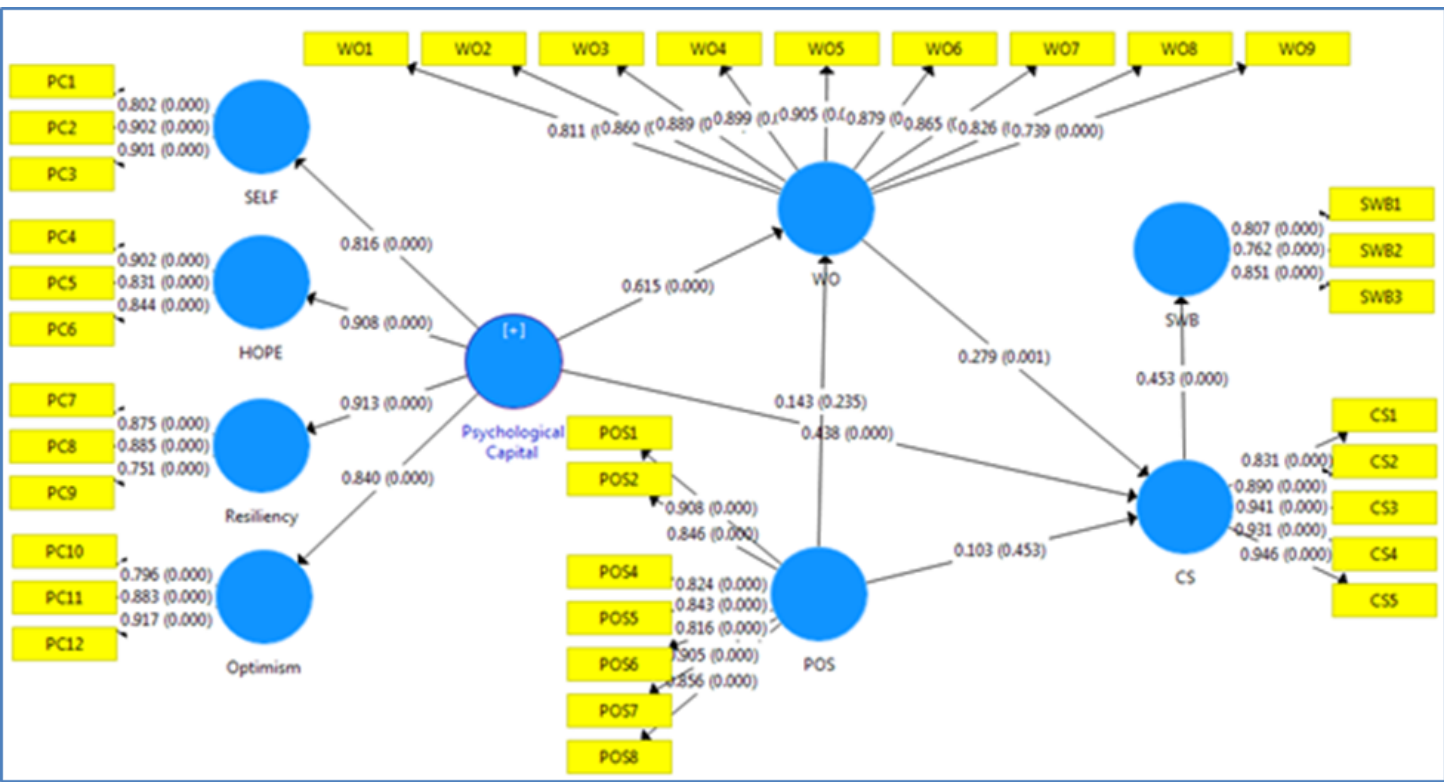

FIGURE 2. OUTER LOADINGS

Source: Smartpls output

Cronbach's alpha values above 0.7 meet the reliability requirements. The SmartPLS output results provide the following Cronbach's alpha values. Cronbach alpha values are sequentially as follows Psychological Capital 0.927, Perceived Organizational Support 0.939, Work Engagement 0.953, Career satisfaction 0.947 and the construct of Individual Subjective Welfare 0.767 . All variables exceeding 0.7 are reliable

\subsection{Hypothesis test}

Based on the results of an analysis conducted to examine the Effect of Psychological Capital and Perceived Organizational Support on Subjective Well Being through Work Engagement and Career Satisfaction as mediators, the results are showing in the table below.

TABLE 2 - PATH COEFFICIENTS (MEAN, STDEV, T-VALUES)

\begin{tabular}{|l|r|r|r|r|r|r|l|}
\hline \multicolumn{1}{|c|}{ Variable } & $\begin{array}{c}\text { Original } \\
\text { Sample } \\
(\mathrm{O})\end{array}$ & $\begin{array}{c}\text { Sample } \\
\text { Mean (M) }\end{array}$ & $\begin{array}{c}\text { Standart } \\
\text { Deviation } \\
(\text { STDEV) }\end{array}$ & $\begin{array}{c}\text { Standart } \\
\text { Error } \\
(\text { STERR) }\end{array}$ & T Stat & Sig P & Conclusion \\
\hline POS $\rightarrow$ CS & 0,103 & 0,152 & 0,137 & 0,092547 & 0,751 & 0,453 & rejected \\
\hline POS $\rightarrow$ WO & 0,143 & 0,177 & 0,121 & 0,084947 & 1,190 & 0,235 & rejected \\
\hline PsyCap $\rightarrow$ CS & 0,438 & 0,406 & 0,106 & 0,130082 & 4,133 & 0,000 & accepted \\
\hline PsyCap $\rightarrow$ WO & 0,615 & 0,591 & 0,101 & 0,152178 & 6,098 & 0,000 & accepted \\
\hline WO $\rightarrow$ CS & 0,279 & 0,260 & 0,082 & 0,113128 & 3,396 & 0,000 & accepted \\
\hline CS $\rightarrow$ SWB & 0,453 & 0,464 & 0,078 & 0,055249 & 5,783 & 0,000 & accepted \\
\hline
\end{tabular}

Source: Smartpls output 
Notes:

POS : Perceived Organizational Support

Psy Cap : Psychological Capital

WO : Work Engagement

CS : Career Satisfaction

SWB : Subjective Well Being

The output path coefficient in the table 2 shows that the influence between Perceived Organizational Support on career satisfaction shows the calculation of the path coefficient to $0.103, \mathrm{t}$ statistics 0.751 , and Sig 0.453 . The results of these statistics prove that there is no definite and statistically significant effect between employee perceptions of the organization on career satisfaction. Therefore, the research hypothesis, which states that there is a significant influence between Perceived Organizational Support on career satisfaction, is rejected.

The influence between Perceived Organizational Support on work involvement shows the calculation of the path coefficient to 0.143 , t-statistics 1.190 , and Sig value 0.235 according to result from number 2. The results of these statistics prove that there is no influence positive and statistically significant evidence between Perceived Organizational Support for work involvement. Therefore, the research hypothesis, which states that there is a significant influence of perceived organizational support on work involvement, is rejected. Hypothesis test results indicate that Perceived Organizational Support does not have a positive and significant impact both on work engagement and career satisfaction. Therefore, it can also be related that POS does not affect the Subjective Welfare of Individuals (Subjectively Well Being), which is second moderated that variable. Account Representative, who is the object of research, understands that they are state civil servants where the institutions where they work are closely related to the rules and policies that are influenced by political and ruling constellations so that the perception of institutional support to individuals is low.

The influence between Psychological Capital (PsyCap) on career satisfaction are shows the calculation of the path coefficient to 0.438 , t-statistics 4.133 , and Sig value 0.00 according to result number 3. This statistical result proves that there is a positive and significant influence between Psychological Capital (PsyCap) on career satisfaction. Therefore, the research hypothesis, which states that there is a significant influence between Psychological Capital (PsyCap) on career satisfaction, is accepted. While according to result, table number 5 shows that the influence between career satisfaction on Individual Subjective Wellbeing shows the calculation of the path coefficient value to 0.453 , t-statistic 5.783 , and Sig value 0.00 . These statistical results prove that there is a positive and significant effect between career satisfaction and Individual Subjective Wellbeing. Therefore, the research hypothesis, which states that 
there is a significant influence between Psychological Capital (PsyCap) on Individual Subjective Wellbeing through career satisfaction, is accepted.

The influence between Psychological Capital (PsyCap) on work involvement shows the calculation of the path coefficient to 0.615 , t-statistics 6.098 , and Sig value 0.00 according to result number 4. These statistical results prove that there is a positive and significant influence between Psychological Capital (PsyCap) on work involvement. Therefore, the research hypothesis, which states that there is a significant influence between Psychological Capital (PsyCap) on work involvement, is accepted. Psychological Capital has a positive effect on individual subjective well-being, which is moderated by variables of work involvement and career satisfaction. In other words, the higher the psychological capital owned by an Account Representative, the higher the Individual Subjective Welfare. Psychological capital, which is characterized by self-efficacy, optimism, hope, and resilience, which is positive psychology in an individual is a personal capital owned by someone to be able to display their abilities optimally. That because they believe in their abilities, feel optimistic about getting maximum results for each work done, have an energy that can motivate them to achieve goals in work done, and have resilience in the face of work failure. The results of this study support the research of Luthans et al. (2007), Luthans et al. (2008), Vankatesh and Blaskovich (2012), Peterson et al. (2011), Dirzyte (2013), and Soleha et al. (2013). Supporting previous studies in Psychological Capital had a significant direct impact on Individual Subjective Wellbeing. (Avey et al., 2010; Choi and Lee, 2014; Culbertson et al., 2010), employees with higher self-efficacy, hope, resiliency, and optimism turned out to be very satisfied with their lives. A Strong positive relationship between Psychological Capital and Individual Subjective Wellbeing indicates that Psychological Capital builds positive attributes about work challenges so that individuals can adjust their behaviour in assessing and mitigating challenges in the work they face (Dolan et al., 2008). In the measurement of Psychological Capital, the Resilience indicator has the most reliable value. Resilience, in this case, can be perceived that respondents who are Accountant Representatives of the Directorate General of Taxes have the "ability to rise or rise again from difficulties, conflicts, failures or even wills towards the positive, the desire to both forward and increased responsibility (Luthans 2002b). It can also represent the spread of patterns and positive adaptation processes to overcome difficulties or risk factors by utilizing personal, social, or psychological assets (Masten et al. 2009). The AR seems to have been aware of the goals of work and individual responsibility, so psychologically, if experiencing difficulties or obstacles, then the individual will find a way out to overcome them.

The influence between works involvement on career satisfaction shows the calculation of the path coefficient value to 0.279 , t-statistic 3.396 , and Sig 0.01 value according to the results of table number 5. These statistical results prove that there is an influence positive and significant between work engagements on career satisfaction. Therefore, the research hypothesis, which states that there is a 
significant influence between job involvement on career satisfaction, is accepted. This result is consistent with research conducted by Schaufeli and Bakker (2004) which shows that workers who are actively involved in their work are energetic and highly skilled individuals who believe that what they do will affect their lives, that is, give satisfaction to a career.

The influence between career satisfaction on Individual Subjective Wellbeing shows the calculation of the path coefficient to 0.453 , t-statistics 5.783 and Sig value 0.00 according to the results of table number 6 . These statistical results prove that there is a positive and significant influence between career satisfaction and Individual Subjective Wellbeing. Therefore, the research hypothesis, which states that there is a significant influence between work engagements on Individual Subjective Wellbeing, is accepted.

\section{CONCLUSIONS}

Human Resources owned by the Directorate General of Taxes are essential assets and pillars in achieving organizational goals. Substantial Psychological Capital owned by the Directorate General of Taxes AR becomes capital for stakeholders, especially Human Resources managers, to be able to build organizational Human Resources so that Account Representatives can perform optimally in achieving organizational goals. For Psychological Capital interventions to be effective, they need to manage in a pleasant environment. Unlike technical training that focuses on developing specific skills and behaviour patterns, the development of Psychological Capital emphasizes positive thinking patterns for challenges, the ability to change direction/assumptions, and deep-rooted beliefs over time. This condition requires a work environment where a positive organizational climate is willing to maintain or at least be open and accept employees who have new ideas and concerns about the organizational environment. If employees who develop are supported, empowered, recognized, valued, valued, permitted to be authentic and innovative, and treated fairly by the organization, Psychological Capital tends to develop and produce desired results (Petersen 2015). The positive impact of Psychological Capital for workers can also be extended to the work environment, family life and even the community where it has social activities. The limitations of this study were conducted in government organizations with high levels of income. So, the job satisfaction tendency is good. For future research, it is suggested to test the theoretical model of this research in organizations other than government organizations. 


\section{REFERENCES}

Armstrong-Stassen, M. and Ursel, N.D. (2009). Perceived Organizational Support, career satisfaction, and the retention of older workers. Journal of Occupational and Organizational Psychology. 82 (1): 201-220

Avery, J. B, Reichard, J. R., Luthans, F. and Mhatre, H. K. (2011). Meta-Analysis of the Impact of Positive Psychological Capital on Employee Attitudes, Behaviors, and Performance. The Journal of Human Resource Development Quarterly 22(2): 127-149

Avery, J. B., Wernsing, T. S. and Luthans, F. (2008). Can positive employees help positive organization change? Impact of psychological capital and emotions on relevant attitudes and behaviours. Journal of Applied Behavioral Science. 44(1): $48-70$

Avery, J.B., Luthans, F., Smith, R.M. and Palmer, N.F. (2010). Impact of positive psychological capital on employee well-being over time. Journal of Occupational Health Psychology. 15(1): 17-28

Avolio, B.J. and Luthans, F. (2006). The High Impact Leader: Moments Matter for Accelerating Authentic Leadership Development, New York: McGraw-Hill

Bakker, A. B. and Demerouti, E. (2008). Towards a model of work engagement. Career Development International. 13(1): 209-223

Carmeli, A., Yitzhak-Halevy, M. and Weisberg, J. (2009). The relationship between emotional intelligence and psychological wellbeing. Journal of Managerial Psychology. 24(1): 66-78

Choi, Y. and Lee, D. (2014). Psychological capital, Big Five traits, and employee outcomes. Journal of Managerial Psychology. 29(1): 122-140

Christopher, J.C. (1999). Situating psychological well-being: Exploring the cultural roots of its theory and research. Journal of Counseling and Development. 77(1): 141-152

Cropanzano, R. and Wright, T.A. (2001). When a 'happy' worker is really a 'productive' worker: A review and further refinement of the happy-productive worker thesis. Consulting Psychology Journal: Practice and Research. 53(3): 182-199

Culbertson, S.S., Fullagar, C.J. and Mills, M.J. (2010). Feeling good and doing great: The relationship between psychological capital and well-being. Journal of Occupational Health Psychology. 15(4): $421-433$

Diener, E., and Biswas-Diener, R. (2008). Happiness: Unlocking the mysteries of psychological wealth. Blackwell Publishing. https://doi.org/10.1002/9781444305159

Dirzyte, A. (2013). Research on Positivity and Psychological Capital at Science and Study Institution in The USA. Intellectual Economics 7 (3): 389-395.

Dolan, P., Peasgood, T. and White, M. (2008). Do we really know what makes us happy? A review of the economic literature on the factors associated with subjective well-being. Journal of Economic Psychology. 29(1): 94-122.

Eisenberger, R., Fasolo, P.M. and Davis-LaMastro, V. (1990). Perceived Organizational Support and employee diligence, commitment, and innovation. Journal of Applied Psychology. 75(1): 51-59

Eisenberger, R., Huntington, R., Hutchison, S. and Sowa, D. (1986). Perceived Organizational Support. Journal of Applied Psychology. 71(1): 500-507

Erdogan, B., Bauer, T. N., Truxillo, D. M., and Mansfield, L. R. (2012). Whistle while you work a review of the life satisfaction literature. Journal of Management. 38(4): 1038-1083 
Gattiker, U. and Larwood, L. (1988). Predictors for manager's career mobility, success and satisfaction. Human Relations. 41(8): 569-91

Gebauer, J., and Lowman, D. (2008). Closing the Engagement Gap: How Great Companies Unlock Employee Potential for Superior Results, New York, NY: Portfolio.

Harter, J.K., Schmidt, F.L. and Hayes, T.L. (2002). Business-unit-level relationship between employee satisfaction, employee engagement, and business outcomes: A meta-analysis. Journal of Applied Psychology. 87(2): 268-279

Irwin. Ng, T.W.H., Eby, L.T., Sorensen, K.L. and Feldman, D.C. (2005). Predictors of objective and subjective career success: A meta-analysis. Personnel Psychology. 58(2): 367-408

Judge, T. A., and Kammeyer-Mueller, J. D. (2011). Happiness as a societal value", The Academy of Management Perspectives. 25(1): 30-41

Judge, T.A., Higgins, C.A., Thoresen, C.J. and Barrick, M.R. (1999). The big five personality traits, general mental ability, and career success across the life span. Personnel Psychology. 52(1): $621-632$

Kahn, W.A. (1990). Psychological conditions of personal engagement and disengagement at work. Academy of Management Journal. 33(4): 692-724

Law, K.S., Wong, C. and Mobley, W.H. (1998). Toward a taxonomy of multidimensional constructs. Academy of Management Review. 23(4): 741-753

Lounsbury, J.W., Loveland, J.M., Sundstrom, E.D., Gibson, L.W., Drost, A.W. and Hamrick, F.L. (2003). An investigation of personality traits in relation to career satisfaction. Journal of Career Assessment. 11(3): 287-307

Luthans, F., Avolio, B. J., Avey, J. B., dan Norman, S. M. (2007). Positive Psychological Capital: Measurement and Relationship with Performance and Satisfaction. Personnel Psychology 60(1): 541-572

Luthans, F., Norman, S. M., Avolio, B. J., dan Avey, J. B. (2008). The Mediating Role of Psychological Capital in the Supportive Organizational Climate-Employee Performance Relationship. Journal of Organizational Behavior 29(1): 219-238

Lyubomirski, S. (2001). Why are some people happier than others? The role of cognitive and motivational processes in well-being. American Psychologist. 56(1): 239-249

Panaccio, A., and Vandenberghe, C. (2010). Perceived Organizational Support, organizational commitment, and employee well-being. Journal of Vocational Behavior. 75(1): 224-236

Petersen, K. (2015). Authentic leadership and unit outcomes: additive and interactive contributions of climate and psychological capital. PhD Thesis, Bellevue Univ., Bellevue, Neb

Peterson, S., Luthans, F., Avolio, B. J., Walumbwa, F., dan Zhang, Z. (2011). Psychological Capital and Employee Performance: A Latent Growth Modeling Approach. Personnel Psychology 64 (2): $427-450$

Rhoades, L., and Eisenberger, R. (2002). Perceived Organizational Support: A review of the literature. Journal of Applied Psychology. 87(1): 698-714

Rich, B.L., Lepine, J.A., and Crawford, E.R. (2010). Job engagement: Antecedents and effects on job performance. Academy of Management Journal. 53(3): 617-635

Saks, A.M. (2006). Antecedents and consequences of employee engagement. Journal of Managerial Psychology. 21(1): 600-619 
THE EFFECTS OF PSYCHOLOGICAL CAPITAL AND PERCEIVED ORGANIZATIONAL SUPPORT ON SUBJECTIVE WELL BEING THROUGH WORK ENGAGEMENT AND CAREER SATISFACTION AS MEDIATORS

Schaufeli, W.B. and Bakker, A.B. (2004). Job demands, job resources, and their relationship with burnout and engagement: A multi-sample study. Journal of Organizational Behaviour. 25(1): 293-315

Soleha, N., Galih, and Lusi, T. (2013). The Effect of Budgetary Participation on Job Performance with Psychological Capital and Organizational Commitment as an Intervening Variable (Empirical Study on Dinas Pendapatan dan Pengelolaan Keuangan Daerah Districts of Lebak). Proceeding. Simposium Nasional Akuntansi XVI

Zelenski, J. M., Murphy, S. A., and Jenkins, D. A. (2008). The happy-productive worker thesis revisited. Journal of Happiness Studies. 9(4): 521-537 